\title{
PENGARUH MODEL DISCOVERY LEARNING TERHADAP KEMAMPUAN PENALARAN MATEMATIS SISWA KELAS VII SMP NEGERI 3 KENDARI
}

\author{
Risa Nurmala, Hafiludin Samparadja, Moh. Salam \\ ${ }^{1)}$ Alumni Jurusan Pendidikan Matematika, ${ }^{2,3)}$ Dosen Jurusan Pendidikan Matematika \\ FKIP Universitas Halu Oleo Email : risanrml@gmail.com ${ }^{1)}$; \\ hafiludin79@yahoo.com; salam_salenda@yahoo.co.id
}

\begin{abstract}
Abstrak
Penelitian ini dilatarbelakangi oleh rendahnya kemampuan penalaran matematis siswa. Populasi dalam penelitian ini adalah seluruh siswa kelas VII SMP Negeri 3 Kendari tahun pelajaran 2017/2018 yang berdistribusi dalam 10 kelas. Teknik pengambilan sampel dalam penelitian ini dilakukan secara purposive sampling, kemudian dipilih 2 kelas sebagai sampel. Data hasil penelitian dikumpulkan melalui pemberian instrumen berupa lembar observasi dan tes kemampuan penalaran matematis. Berdasarkan hasil analisis data dan pembahasan diperoleh kesimpulan: 1) persentasekeaktifan siswa dengan menggunakan model discovery learning pada 5 kali pertemuan, yaitu $70,59 \%$ sampai $88,24 \%$, (2) Rata-rata kemampuan penalaran matematis siswa yang diajar dengan model discovery learning 79,16 (3) Rata-rata kemampuan penalaran matematis siswa yang diajar dengan model pembelajaran konvensional 71,59 dan (4) Berdasarkan uji t, menunjukkan bahwa kemampuan penalaran matematis siswa yang diajar dengan model discovery learning lebih tinggi daripada siswa yang diajar dengan model pembelajaran konvensional.
\end{abstract}

Kata Kunci : model pembelajaran discovery learning, kemampuan penalaran matematis

\section{INFLUENCE OF DISCOVERY MODEL ON THE ABILITY OF MATHEMATIC REASONING STUDENTS OF CLASS VII SMP NEGERI 3 KENDARI}

\begin{abstract}
This research is motivated by the low ability of mathematical reasoning students. The population in this research is all students of class VII in SMP Negeri 3 Kendari academic year 2017/2018 which is distributed in 10 classes. The interpretation sampling in this research by using purposive sampling, then selected 2 classes as sample. The data of this research were collected by giving the instrument observation sheet and mathematical reasoning test. Based on the results of data analysis and discussion obtained conclusion: 1) the percentage of student activity by using Discovery Learning model on 5 times meetings, that is $70,59 \%$ to $88,24 \%$, (2) the average of mathematical reasoning students with Discovery Learning model that is 79,16 , (3) the average of mathematical reasoning students with conventional model that is 71,59 and (4) Based on t-test, showing that ability reasoning mathematic by using Discovery Learning model higher than students direct by conventional model.
\end{abstract}

Keywords: discovery learning, student mathematical reasoning ability. 


\section{Pendahuluan}

Pendidikan adalah hal pokok yang akan menopang kemajuan suatu bangsa. Kemajuan suatu bangsa dapat diukur dari kualitas dan sistem pendidikan yang ada. Tanpa pendidikan, suatu negara akan tertinggal jauh dari negara lain. Kualitas pendidikan di Indonesia pada dewasa ini sangat memprihatinkan. Hal ini dibuktikan dari hasil riset PISA (Program for International Student Assessment) pada tahun 2015 untuk rata-rata skor pencapaian siswa Indonesia untuk sains, membaca dan matematika hanya berada di peringkat 10 besar terbawah dari 69 negara.

Menurut Kementerian Pendidikan dan Kebudayaan, dari sekian banyak unsur sumber daya pendidikan, kurikulum merupakan salah satu unsur yang memberikan kontribusi yang signifikan untuk mewujudkan proses berkembangnya kualitas potensi peserta didik. Jadi, tidak dapat disangkal lagi bahwa kurikulum yang dikembangkan dengan berbasis pada kompetensi sangat diperlukan sebagai instrumen untuk mengarahkan peserta didik menjadi: (1) manusia berkualitas yang mampu dan proaktif menjawab tantangan zaman yang selalu berubah; (2) manusia terdidik yang beriman dan bertakwa kepada Tuhan Yang Maha Esa, berakhlak mulia, sehat, berilmu, cakap, kreatif, mandiri; dan (3) warga negara yang demokratis, bertanggung jawab.

Upaya pemerintah dalam meningkatkan kualitas pendidikan adalah dengan perubahan kurikulum. Perubahan kurikulum di Indonesia dimulai dari diterapkannya Kurikulum 1994, Kurikulum berbasis Kompetensi (KBK), Kurikulum Tingkat Satuan Pendidikan (KTSP), dan Kurikulum 2013 yang diberlakukan sejak tahun 2013 sampai sekarang.

Kurikulum 2013 dirancang dengan tujuan untuk mempersiapkan insan Indonesia supaya memiliki kemampuan hidup sebagai pribadi dan warganegara yang beriman, produktif, kreatif, inovatif, dan afektif serta mampu berkontribusi pada kehidupan bermasyarakat, berbangsa, bernegara dan peradaban dunia. Kurikulum adalah instrumen pendidikan untuk dapat membawa insan Indonesia memiliki kompetensi sikap, pengetahuan, dan keterampilan sehingga dapat menjadi pribadi dan warga negara yang produktif, kreatif, inovatif, dan afektif.
Pembelajaran Kurikulum 2013 adalah pembelajaran kompetensi dengan memperkuat proses pembelajaran dan penilaian autentik untuk mencapai kompetensi sikap, pengetahuan dan keterampilan. Penguatan proses pembelajaran dilakukan melalui pendekatan saintifik, yaitu pembelajaran yang mendorong siswa lebih mampu dalam mengamati, menanya, mencoba/mengumpulkan data, mengasosiasi/menalar, dan mengomunikasikan.

Aspek-aspek dalam pendekatan saintifik terdiri dari: (a) mengamati, (b) menanya, (c) mencoba, (d) menalar dan (e) mengkomunikasikan. Menalar atau penalaran terfokus pada upaya merumuskan kesimpulan berdasarkan beberapa pernyataan yang dianggap benar. Penalaran juga merupakan aktivitas berpikir yang abstrak. Untuk mewujudkannya diperlukan simbol dan cara berpikir sistematis. Simbol atau lambang yang digunakan dalam penalaran berbentuk bahasa, sehingga wujud penalaran akan berupa argumen.

Matematika pada dasarnya suatu alat untuk mengembangkan cara berpikir. Oleh karena itu, matematika sangat diperlukan baik dalam kehidupan sehari-hari maupun dalam menghadapi kemajuan Ilmu Pengetahuan dan Teknologi (IPTEK) sehingga perlu dibekalkan kepada siswa. Matematika pada hakikatnya merupakan suatu ilmu yang cara bernalarnya deduktif formal dan abstrak. Tujuan pembelajaran matematika untuk melatih cara berpikir dan bernalar siswa dalam menarik kesimpulan.

Kemampuan bernalar memiliki peran penting dalam pembelajaran matematika. Dalam pembelajaran matematika siswa dilatih untuk berpikir dan bernalar dalam menarik kesimpulan. Materi matematika dan penalaran matematika merupakan dua hal yang tidak dapat dipisahkan. Materi matematika dipahami melalui penalaran, dan penalaran dipahami dan dilatihkan melalui belajar matematika, sehingga kemampuan penalaran matematis sangat penting dan dibutuhkan dalam mempelajari matematika. Penalaran matematika diperlukan untuk menentukan apakah sebuah argumen matematika benar atau salah dan dipakai untuk membangun suatu argumen matematika. Penalaran matematika tidak hanya penting untuk melakukan pembuktian atau pemeriksaan program, tetapi juga untuk inferensi dalam suatu sistem kecerdasan buatan. 
Berdasarkan hasil wawancara dengan guru mata pelajaran matematika kelas VII SMP Negeri 3 Kendari yaitu Ibu Rini Indrawati, S.Pd pada hari Sabtu, 25 November 2017, bahwa kemampuan penalaran matematis siswa kelas VII masih tergolong rendah. Hal ini tergambar dari rata-rata hasil tes kemampuan penalaran matematis siswa kelas VII SMP Negeri 3 Kendari Kelas $\mathrm{VII}_{\mathrm{A}}$ yaitu 55,9, kelas $\mathrm{VII}_{\mathrm{B}}$ yaitu 42,3, kelas $\mathrm{VII}_{\mathrm{C}}$ yaitu 45,1 , kelas $\mathrm{VII}_{\mathrm{D}}$ yaitu 53,2 , kelas $\mathrm{VII}_{\mathrm{E}}$ yaitu 47,5 , kelas $\mathrm{VII}_{\mathrm{F}}$ yaitu 50,0 , kelas $\mathrm{VII}_{\mathrm{G}}$ yaitu 48,9 , kelas $\mathrm{VII}_{\mathrm{H}}$ yaitu 52,0, kelas $\mathrm{VII}_{\mathrm{I}}$ yaitu 52,4, kelas $\mathrm{VII}_{\mathrm{J}}$ yaitu 40,0. Berdasarkan hasil tes awal kemampuan penalaran matematis diperoleh bahwa kemampuan penalaran matematis siswa kelas VII SMP Negari 3 Kendari tergolong rendah.

Terdapat beberapa faktor yang yang mempengaruhi rendahnya hasil kemampuan penalaran matematis di SMP Negeri 3 Kendari. Salah satunya kurangnya soal-soal penalaran yang diberikan guru. Soal-soal yang diberikan hanya terpusat pada satu buku saja. Guru tidak berinisiatif untuk menambah soal-soal berbentuk penalaran dari sumber lain. Hal ini berdampak pada siswa karena tidak terbiasa dihadapkan dengan soal-soal berbentuk penalaran. Selain itu siswa masih sering dibiasakan menghafal rumus. Akibatnya, ketika siswa diberikan soal bentuk berbeda dengan materi yang hampir mirip, siswa tidak bisa mengerjakan soalnya lagi dan jawaban siswa tidak sistematis. Faktor berikutnya adalah siswa tidak mau aktif dalam menemukan solusi dari suatu permasalahan matematika. Hal ini dikarenakan pada materi dasar matematika siswa sudah tidak mau aktif mengolah materi yang ada dan mengembangkan sendiri materi itu.

Menurut Fitmawati (2015: 3) discovery learning merupakan model pembelajaran yang lebih menekankan pada ditemukannya konsep atau prinsip yang sebelumnya tidak diketahui pada pengajaran dan keterampilan pemecahan masalah, yang diikuti dengan penguatan keterampilan. Dengan menggunakan model pembelajaran ini siswa diharapkan mampu mengembangkan kemampuan berpikirnya dan untuk menemukan penyelesaian dari suatu permasalahan yang diberikan.

Metode ini dapat membantu siswa memperkuat konsep dirinya, karena memperoleh kepercayaan bekerja sama dengan yang lainnya, berpusat pada siswa dan guru berperan samasama aktif mengeluarkan gagasan-gagasan. Bahkan gurupun dapat bertindak sebagai siswa, dan sebagai peneliti di dalam situasi diskusi. membantu dan mengembangkan ingatan dan transfer kepada situasi proses belajar yang baru, mendorong siswa berfikir intuisi dan merumuskan hipotesis sendiri. Dengan demikian diharapkan dengan menggunakan model pembelajaran ini prestasi belajar matematika siswa akan lebih baik.

Menurut Suprihatiningrum $(2016 ; 218)$ membagi langkah-langkah pembelajaran discovery learning menjadi 6 tahap seperti pada table berikut

Tabel 1

Sintaks Model Pembelajaran Discovery learning

\begin{tabular}{|l|l|l|}
\hline No & Tahap-Tahap & Kegiatan Guru \\
\hline 1. & $\begin{array}{l}\text { Menjelaskan tujuan atau } \\
\text { mempersiapkan siswa }\end{array}$ & $\begin{array}{l}\text { Menyampaikan tujuan pembelajaran, memotivasi siswa } \\
\text { dengan mendorong siswa untuk terlibat dalam kegiatan }\end{array}$ \\
\hline 2. & Orientasi siswa pada masalah & $\begin{array}{l}\text { Menjelaskan masalah sederhana yang berkenaan dengan } \\
\text { materi pembelajaran }\end{array}$ \\
\hline 3. & Merumuskan hipotesis & $\begin{array}{l}\text { Membimbing siswa merumuskan hipotesis sesuai } \\
\text { permasalahan yang dikemukakan }\end{array}$ \\
\hline 4. & Melakukan kegiatan penemuan & $\begin{array}{l}\text { Membimbing siswa melakukan kegiatan penemuan } \\
\text { dengan mengarahkan siswa untuk memperoleh informasi } \\
\text { yang diperlukan }\end{array}$ \\
\hline 5. & $\begin{array}{l}\text { Mempresentasikan hasil } \\
\text { kegiatan penemuan }\end{array}$ & $\begin{array}{l}\text { Membimbing siswa dalam menyajikan hasil kegiatan, } \\
\text { merumuskan kesimpulan atau menemukan konsep }\end{array}$ \\
\hline
\end{tabular}




\begin{tabular}{|l|l|l}
\hline 6. & $\begin{array}{l}\text { Mengevaluasi kegiatan } \\
\text { penemuan }\end{array}$ & $\begin{array}{l}\text { Mengevaluasi langkah-langkah kegiatan yang telah } \\
\text { dilakukan }\end{array}$ \\
\hline
\end{tabular}

Menurut Berlyne dalam Ansyar (2015: 233) ada beberapa manfaat model pembelajaran discovery learning yaitu : (1) merangsang keinginan tahu siswa sehingga memotivasi mereka untuk terus bekerja menemukan jawaban atas keinginan tahu itu, (2) siswa belajar cara atau teknik pemecahan masalah secara mandiri serta cara berpikir kritis, sebab siswa harus melakukan analisis dan manipulasi berbagai informasi terkait. kelebihan model pembelajaran discovery learning sebagai berikut: 1) Membantu siswa melaksanakan hakikat sesungguhnya pembelajaran, yaitu perolehan informasi dan aplikasinya ke situasi baru dan ke pemecahan masalah, 2) Melatih siswa agar tidak selalu tergantung pada faktor eksternal, seperti persetujuan guru, hadiah orang tua, atau penghindaran kegagalan untuk menimbulkan motivasi intrinsik, sebab siswa yang berhasil melakukan suatu penemuan memperoleh kepuasan diri atas hasil temuannya itu. Dan 3) Materi pelajaran melalui penemuan memiliki retensi yang lebih lama daripada materi yang diajarkan guru, sebab materi itu diorganisasi berdasarkan interes itu sendiri, sehingga lebih siap direproduksi jika diperlukan.

Pembelajaran penemuan terbimbing (guided discovery learning) merupakan model

(Suprihatiningrum, 2016: 248)

pembelajaran yang menciptakan situasi belajar yang melibatkan peserta didik belajar secara aktif dan mandiri dalam menemukan suatu konsep atau teori, pemahaman, dan pemecahan masalah. Proses penemuan tersebut membutuhkan guru sebagai fasilitator dan pembimbing. Banyaknya bantuan yang diberikan guru tidak mempengaruhi peserta didik untuk melakukan penemuan sendiri (Priansa, 2015: 219).

\section{Metode}

Penelitian yang dilaksanakan adalah penelitian eksperimen posttest only control group design yaitu penelitian yang menggunakan posttest pada pertemuan terakhir untuk menentukan pengaruh suatu kelompok (eksperimen ) yang diberi perlakuan model pembelajaran Discovery Learning dan suatu kelompok (kontrol) yang diberi perlakuan model pembelajaran konvensional.

Populasi dalam penelitian ini adalah seluruh siswa kelas VII di SMP Negeri 3 Kendari yang terdaftar pada Tahun Ajaran 2017/2018 yang tersebar pada 10 kelas paralel yaitu kelasVII ${ }_{\mathrm{A}}$ sampai $\mathrm{VII}_{\mathrm{H}}$ yang disajikan dalam tabel 2 berikut

Tabel 2

Populasi Siswa Kelas VII dengan Nilai Rata-rata Tes Awal Kemampuan Penalaran Matematis Mata Pelajaran Matematika

\begin{tabular}{|c|c|c|}
\hline Kelas & Jumlah Siswa & $\begin{array}{c}\text { Rata-Rata Hasil Tes Awal Kemampuan } \\
\text { Penalaran Matematis }\end{array}$ \\
\hline VII.A & 32 & 55,9 \\
\hline VII.B & 28 & 42,3 \\
\hline VII.C & 32 & 45,1 \\
\hline VII.D & 30 & 53,2 \\
\hline VII.E & 31 & 47,5 \\
\hline VII.F & 26 & 50,0 \\
\hline VII.G & 31 & 48,9 \\
\hline VII.H & 21 & 52,0 \\
\hline VII.I & 22 & 52,4 \\
\hline VII.J & 24 & 40,0 \\
\hline
\end{tabular}

(sumber : hasil tes awal kemampuan penalaran matematis)

Pengambilan sampel pada penelitian ini dilakukan dengan teknik purposive sampling yaitu pertimbangan mengambil dua kelas yang memiliki kemampuan yang relative sama. Dari cara tersebut diperoleh kelas $\mathrm{VII}_{\mathrm{H}}$ dan $\mathrm{VII}_{\mathrm{I}}$ yang memiliki nilai rata-rata yang relative sama. Penentuan kelas eksperimen dan kelas kontrol dilakukan dengan tekning random dimana kelas 
$\mathrm{VII}_{\mathrm{H}}$ sebagai kelas eksperimen yang diajar dengan model Discovery Learning dan kelas $\mathrm{VII}_{\mathrm{I}}$ sebagai kelas kontrol yang diajar dengan model pembelajaran konvensonal.

Desain penelitian yang digunakan adalah posttest only control design yaitu penelitian melibatkan dua kelas sampel (kelas eksperimen dan kelas kontrol) dimana kelas eksperimen diberi perlakuan (X) dan kelas kontrol tidak diberi perlakuan. Desain penelitian disajikan dalam tabel berikut:

Tabel 3

Desain penelitian posttest only control design

\begin{tabular}{|c|c|c|}
\hline Kelas & Perlakuan & Posttest \\
\hline $\mathrm{E}$ & $\mathrm{X}$ & $\mathrm{O}_{1}$ \\
\hline $\mathrm{K}$ & & $\mathrm{O}_{2}$ \\
\hline
\end{tabular}

Keterangan:

$$
\begin{aligned}
& \mathrm{E}=\text { Eksperimen } \\
& \mathrm{K}=\text { Kontrol } \\
& \mathrm{X}=\text { Perlakuan berupa penerapan }
\end{aligned}
$$

model Discovery Learning pada kelas eksperimen eksperimen

$$
\mathrm{O}_{1}=\text { Hasil posttest siswa pada kelas }
$$

kontrol

$$
\mathrm{O}_{2}=\text { Hasil posttest siswa pada kelas }
$$

Instrumen pengumpulan data adalah alat bantu yang dipilih dan digunakan oleh peneliti dalam kegiatannya mengumpulkan data agar kegiatan tersebut menjadi sistematis dan dipermudah olehnya (Arikunto, 2002: 206). Penelitian ini mempunyai dua instrumen, yaitu lembar observasi dan tes uraian sebanyak delapan butir soal.

mengukur

Lembar observasi digunakan untuk (terlaksana/tidaknya) model discovery learning, di dalam penelitian ini menggunakan lembar pengamatan/observasi pada setiap kali pertemuan. Lembar observasi ini dibuat oleh guru dan diisi oleh observer. Lembar pengamatan ini terdiri atas 2 jenis, yaitu lembar observasi aktivitas guru dan lembar observasi aktivitas siswa dalam pembelajaran model discovery learning. Lembar pengamatan yang dibuat bertujuan untuk mengontrol setiap tindakan/aktivitas yang dilakukan oleh guru dan siswa dalam kelas pada tiap pertemuan.

Kemampuan penalaran matematis dalam penelitian ini adalah total skor yang di capai siswa setelah mengerjakan tes kemampuan penalaran matematis yang berbentuk soal esai yang terdiri dari 4 butir soal pada materi garis dan sudut yang disusun oleh peneliti. Awalnya instrumen berjumlah 8 butir soal yang sebelumnya telah ditelaah oleh pembimbing,
(Sugiyono, 2009: 76).

dosen dan guru. Di samping pertimbangan terhadap validitas muka yakni, kejelasan bahasa/ redaksional dan gambar/representasi, dilakukan pula validitas isi, yakni kesesuaian materi tes dengan kisi-kisi tes, tujuan yang ingin dicapai, indikator kemampuan penalaran matematis yang diukur, dan tingkat kesukaran setiap butir soal kemampuan penalaran matematis, pembimbing juga memberikan beberapa saran perbaikan redaksi beberapa butir soal.

Setelah ditelaah instrumen yang dipilih sebanyak 8 butir soal dan diujicoba pada tanggal 7 Maret 2018 di kelas VIII 1 SMP Negeri 8 Kendari untuk mengetahui validitas dan reliabilitas soal.

Validitas mengacu pada keberartian, kebenaran, kemanfaatan, dan kesesuaian skor tes. Validitas merupakan karakteristik suatu tes ketika diujikan pada suatu kelompok peserta tes. Validasi suatu instrumen mencakup pengumpulan data dan argumentasi logis untuk menunjukkan bahwa kesimpulan tertentu adalah tepat (Ahiri dan Hafid, 2011: 243).

Reliabilitas yang berarti konsistensi adalah ciri umum dari suatu instrumen pengukuran dan penilaian pendidikan. Konsistensi tinggi skor instrumen dari suatu pengukuran ke pengukuran berikutnya merupakan ciri terpenting dari instrumen yang berkualitas tinggi (Ahiri dan Hafid, 2011: 243). Reliabilitas (reliability, kepercayaan) menunjuk pada suatu instrumen dapat mengukur sesuatu yang akan diukur secara konsisten atau tidak berubah-ubah dari waktu ke waktu. Suatu instrumen dapat dipercaya untuk digunakan sebagai alat pengumpul data jika telah diuji reliabilitasnya. 
Selanjutnya dalam pemberian interpretasi terhadap koefisien reliabilitas tes ( $r_{11}$ ) pada umumnya digunakan patokan :

$\mathrm{r}_{11} \leq 0,20$ reliabilitas : sangat rendah

$0,20<\mathrm{r}_{11} \leq 0,40$

$0,40<\mathrm{r}_{11} \leq 0,60$

$0,60<\mathrm{r}_{11} \leq 0,80$

$0,80<\mathrm{r}_{11} \leq 1,00$ tinggi

reliabilitas : rendah

reliabilitas : sedang

reliabilitas : tinggi

reliabilitas : sangat

(Ruseffendi

dalam Jihad dan Haris, 2008: 181).

Tes yang diberikan pada siswa dalam penelitian ini berbentuk esai (uraian) agar siswa dapat menggunakan kalimat-kalimat yang mereka susun sendiri untuk memecahkan soal/masalah yang ada. Untuk memperoleh data dalam penelitian ini dilaksanakan tes hasil kemampuan penalaran matematis siswa. Tes ini dilakukan kepada kelas eksperimen dan kelas kontrol setelah diberikan perlakuan dengan tujuan mendapatkan data akhir. Dari tes tersebut dilakukan penskoran terhadap jawaban siswa untuk tiap butir soal. Pemberian skor pada tes kemampuan penalaran matematis siswa menggunakan pedoman penskoran dari Jamilun (2016), sebagaimana dapat dilihat pada tabel berikut.

Tabel 4

Pedoman Penskoran Kemampuan Penalaran Matematis Siswa

\begin{tabular}{|c|c|c|}
\hline $\begin{array}{l}\text { Indikator Penalaran } \\
\text { Matematis }\end{array}$ & Reaksi terhadap Masalah & Skor \\
\hline \multirow{5}{*}{$\begin{array}{l}\text { Menyajikan pernyataan } \\
\text { matematika secara lisan, } \\
\text { tertulis, gambar dan } \\
\text { diagram }\end{array}$} & Tidak ada jawaban & 0 \\
\hline & $\begin{array}{l}\text { Tidak menyajikan pernyataan matematika baik secara tertulis, } \\
\text { gambar, ataupun diagram dan melakukan perhitungan tetapi salah }\end{array}$ & 1 \\
\hline & $\begin{array}{l}\text { Tidak menyajikan pernyataan matematika baik secara tertulis, } \\
\text { gambar, ataupun diagram dan melakukan perhitungan tetapi benar }\end{array}$ & 2 \\
\hline & $\begin{array}{l}\text { Menyajikan pernyataan matematika baik secara tertulis, gambar, } \\
\text { ataupun diagram dan melakukan perhitungan tetapi salah }\end{array}$ & 3 \\
\hline & $\begin{array}{l}\text { Menyajikan pernyataan matematika baik secara tertulis, gambar, } \\
\text { ataupun diagram dan melakukan perhitungan dengan benar }\end{array}$ & 4 \\
\hline \multirow{5}{*}{$\begin{array}{l}\text { Melakukan manipulasi } \\
\text { Matematika }\end{array}$} & Tidak ada jawaban & 0 \\
\hline & $\begin{array}{l}\text { Tidak melakukan manipulasi matematika dan melakukan } \\
\text { perhitungan tetapi salah }\end{array}$ & 1 \\
\hline & $\begin{array}{l}\text { Tidak melakukan manipulasi matematika dan melakukan } \\
\text { perhitungan dengan benar }\end{array}$ & 2 \\
\hline & $\begin{array}{l}\text { Melakukan manipulasi matematika dan melakukan perhitungan } \\
\text { tetapi salah }\end{array}$ & 3 \\
\hline & $\begin{array}{l}\text { Melakukan manipulasi matematika dan melakukan perhitungan } \\
\text { dengan benar }\end{array}$ & 4 \\
\hline \multirow{5}{*}{$\begin{array}{l}\text { Memeriksa kesahihan } \\
\text { suatu argument }\end{array}$} & Tidak ada jawaban & 0 \\
\hline & $\begin{array}{l}\text { Tidak memeriksa kesahihan suatu argument dan melakukan } \\
\text { perhitungan tetapi salah }\end{array}$ & 1 \\
\hline & $\begin{array}{l}\text { Tidak memeriksa kesahihan suatu argument dan melakukan } \\
\text { perhitungan dengan benar }\end{array}$ & 2 \\
\hline & $\begin{array}{l}\text { Memeriksa kesahihan suatu argument dan melakukan perhitungan } \\
\text { tetapi salah }\end{array}$ & 3 \\
\hline & $\begin{array}{l}\text { Memeriksa kesahihan suatu argument dan melakukan perhitungan } \\
\text { dengan benar }\end{array}$ & 4 \\
\hline \multirow{5}{*}{$\begin{array}{l}\text { Menarik kesimpulan dari } \\
\text { pernyataan }\end{array}$} & Tidak ada jawaban & 0 \\
\hline & $\begin{array}{l}\text { Tidak menarik kesimpulan dari pernyataan dan melakukan } \\
\text { perhitungan tetapi salah }\end{array}$ & 1 \\
\hline & $\begin{array}{l}\text { Tidak menarik kesimpulan dari pernyataan dan melakukan } \\
\text { perhitungan dengan benar }\end{array}$ & 2 \\
\hline & $\begin{array}{l}\text { Menarik kesimpulan dari pernyataan dan melakukan perhitungan } \\
\text { tetapi salah }\end{array}$ & 3 \\
\hline & $\begin{array}{l}\text { Menarik kesimpulan dari pernyataan dan melakukan perhitungan } \\
\text { dengan benar }\end{array}$ & 4 \\
\hline
\end{tabular}


Adapun cara perhitungan nilai akhir adalah sebagai berikut.

$$
\mathrm{N}=\frac{\text { skor perole han }}{\text { skor maksimal }} \times 100
$$

dengan $N$ sebagai nilai akhir.

Analisis data dalam penelitian ini menggunakan analisis deskriptif dan analisis inferensial. Analisis deskriptif digunakan untuk mendeskriptifkan karakteristik data masingmasing kelompok dan analisis inferensial digunakan untuk menguji hipotesis dengan statistik uji-t.Analisis deskriptif digunakan untuk memperoleh data tentang aktivitas/partisipasi guru dan siswa dalam pembelajaran. Analisis deskriptif juga dimaksudkan untuk mendeskripsikan kemampuan penalaran matematis siswa melalui skor rata-rata yang diperoleh siswa baik pada kelas eksperimen maupun kelas kontrol. Analisis deskriptif hanya melihat gambaran sampel dalam bentuk ratarata $(\bar{x})$, median $(\mathrm{Me})$, modus $(\mathrm{Mo})$, standar

(Jamilun: 2016).

deviasi (s), varians, skewness, kurtosis, nilai maksimum $\left(x_{\max }\right)$, dan nilai minimum $\left(x_{\min }\right)$.

Analisis deskriptif juga dimaksudkan untuk mendeskripsikan kemampuan penalaran matematis siswa dan indikator kemampuan penalaran matematis siswa. Analisis inferensial dimaksudkan untuk menguji hipotesis penelitian, namun terlebih dahulu melalui tahapan-tahapan yang lain, yaitu uji normalitas dan uji homogenitas sebagai prasyarat untuk pengujian hipotesis.

\section{Hasil}

Hasil observasi aktivitas guru terhadap pelaksanaan pembelajaran matematika pada kelas eksperimen yang diajar dengan menggunakan model pembelajaran discovery learning pada materi garis dan sudut dapat dilihat pada tabel 5 .

\section{Tabel 5}

Hasil Observasi Aktivitas Guru Dalam Pembelajaran Discovery Learning

\begin{tabular}{|c|c|c|}
\hline Pertemuan & $\begin{array}{c}\text { Skor Total } \\
\text { Keberhasilan Guru }\end{array}$ & Persentase (\%) \\
\hline Pertama & 17 & 73.91 \\
\hline Kedua & 18 & 78.26 \\
\hline Ketiga & 19 & 82.61 \\
\hline Keempat & 20 & 86.96 \\
\hline Kelima & 22 & 95.65 \\
\hline
\end{tabular}

Berdasarkan Tabel 5, keberhasilan pengelolaan pembelajaran pada pertemuan pertama sudah baik dengan tingkat keberhasilan sebesar 73,91 \%. Namun, pada pertemuan pertama ini guru lupa memberikan motivasi, tujuan pembelajaran serta garis-garis besar kegiatan pembelajaran discovery learning kepada siswa untuk kegiatan pendahuluan. Pada kegiatan inti, guru lupa meminta siswa untuk mengolah atau menghitung jawaban apakah sesuai dengan hipotesis atau tidak, guru langsung membimbing siswa dalam pengolahan data. Pada akhir kegiatan inti, guru dan siswa tidak bersama-sama membuat kesimpulan dari materi yang dipelajari dikarenakan guru belum mampu mengorganisasikan waktu dengan optimal. Selanjutnya, pada kegiatan penutup guru tidak menginformasikan materi pembelajaran pada pertemuan berikutnya .
Pelaksanaan pembelajaran pada pertemuan kedua mengalami peningkatan dibanding pada pertemuan pertama. Tingkat keberhasilan mencapai 78,26\% dengan kategori baik. Tetapi seperti pada pertemuan sebelumnya, guru tidak memberikan motivasi dan tujuan pembelajaran kepada siswa, melainkan guru langsung memulai proses pembelajaran seperti biasanya menggunakan model discovery learning. Pada kegiatan inti, guru tidak lagi membagi siswa dalam kelompok berpasangan karena siswa telah mengambil posisi pada kelompoknya seperti pembelajaran pada pertemuan pertama. Pada pertemuan kedua ini juga, guru lupa untuk membuat kesimpulan dari materi yang telah dipelajari. Sedangkan, pada kegiatan penutup, guru tidak menginformasikan materi pembelajaran pada pertemuan berikutnya dikarenakan keterbatasan waktu. Pertemuan ketiga persentasi pengolaan kelas mengalami 
peningkatan dari pertemuan kedua dengan keberhasilan yaitu $82,61 \%$ dengan kategori baik dimana guru masih mendominasi keadaan kelas dan mulai terbiasa menerapkan model pembelajaran discovery learning, namun pada kegiatan pendahuluan guru tidak lagi menyampaikan garis-garis besar kegiatan model pembelajaran discovery learning. Pada kegiatan inti, guru juga tidak membagi siswa dalam kelompok belajar seperti pada pertemuan sebelumnya, tetapi guru langsung memberikan stimulus dengan mengajukan pertanyaan tentang materi yang akan diajarkan. Karena keterbatasan waktu, pada kegiatan penutup guru lupa untuk menyampaikan materi pelajaran yang akan dipelajari pada pertemuan selanjutnya.

Pelaksanaan pembelajaran pada pertemuan keempat mengalami peningkatan dari pertemuan ketiga. Tingkat keberhasilan mencapai $86,96 \%$ dengan kategori sangat baik. Dimana guru telah melaksanakan seluruhnya pada kegiatan pendahuluan, pada kegiatan inti juga guru tidak lagi mengorganisasikan siswa pada kelompok belajarnya. Pada kegiatan penutup, karena keterbatasan waktu guru tidak menyampaikan materi yang akan dipelajari selanjutnya. Pada pertemuan terakhir, persentase pertemuan ini meningkat yaitu $95.65 \%$ dimana hampir semua kegiatan pembelajaran telah dilakukan hanya saja, guru tidak lagi memberikan tugas untuk karena pertemuan selanjutnya dilakukan ulangan. Dari hasil observasi tersebut, terlihat bahwa pengelolaan pembelajaran oleh guru mengalami peningkatan pada setiap pertemuan mengingat model pembelajaran yang baru diterapkan peneliti, namun pada akhir penerapannya peneliti mampu menerapkan model pembelajaran dengan baik.

Hasil observasi aktivitas siswa dalam pelaksanaan pembelajaran dengan model pembelajaran Discovery Learning dapat terlihat dalam tabel berikut.

Tabel 6

Hasil Observasi Aktivitas Siswa Dalam Pembelajaran Model Discovery Learning

\begin{tabular}{|l|c|c|}
\hline \multicolumn{1}{|c|}{ pertemuan } & $\begin{array}{c}\text { Skor perolehan } \\
\text { (keterlaksanaan) }\end{array}$ & Persentase \\
\hline Pertama & 12 & $70,59 \%$ \\
\hline Kedua & 13 & $76,47 \%$ \\
\hline Ketiga & 13 & $76,47 \%$ \\
\hline Keempat & 14 & $82,35 \%$ \\
\hline Kelima & 15 & $88,24 \%$ \\
\hline
\end{tabular}

Berdasarkan Tabel 6, Berdasarkan tabel tersebut, persentase keaktifan siswa pada pertemuan pertama mencapai 70,59\%. Pada pertemuan tersebut, mayoritas siswa tidak mendengarkan tujuan pembelajaran yang diberikan oleh guru. karena masih menyesuaikan diri dengan guru, siswa mayoritas tidak bertanya kepada teman atau guru jika mengalami kesulitan dalam penyelesaian masalah, siswa juga tidak melakukan kerjasama yang aktif dan terarah. Karena keterbatasan waktu, siswa tidak menyimpulkan hasil pembelajaran dan tidak mendengarkan materi yang akan dipelajari pada pertemuan selanjutnya.

Pertemuan kedua persentase keaktifan siswa tidak mengalami peningkatan dari pertemuan pertama dengan keberhasilan yang sama dengan yaitu $76,47 \%$. Pada pertemuan kedua ini, mayoritas siswa tidak mendengarkan tujuan pembelajaran yang disampaikan guru, tetapi mayoritas siswa sudah mulai membiasakan diri dengan guru sehingga siswa sudah mulai bertanya jika mengalami kesulitan dalam menemukan penyelesaian masalah. Pada pertemuan kedua ini, siswa tidak mempresentasikan hasil diskusinya di depan kelas karena guru lupa mempersilahkan siswa, serta siswa tidak memberi tanggapan jika ada jawaban yang berbeda. Kemudian, pada pertemuan ketiga, persentase keaktifan siswa tidak mengalami peningkatan maupun penurunan dengan persentase tetap yaitu 76,47 $\%$. Pada pertemuan ketiga ini siswa mayoritas tidak mengingat kembali materi yang terkait dengan materi pembelajaran yang akan diajarkan. Siswa juga tidak aktif dalam melakukan kegiatan kelompok, serta pada akhir 
pertemuan siswa tidak mendengar materi yang akan dipelajari selanjutnya. Pada pertemuan keempat persentase aktifitas siswa meningkat mencapai $82,35 \%$ dimana hampir semua aktifitas siswa dikerjakan dengan baik hanya saja, pada akhir pembelajaran siswa tidak menyimpulkan hasil dari pembelajaran yang telah dipelajari, serta tidak mendengarkan materi yang akan dipelajari selanjutnya. Pada pertemuan kelima, persentase aktifitas siswa meningkat dengan persentase $88,24 \%$ dimana aktifitas siswa hampir dilakukan sepenuhnya, hanya saja siswa tidak mencatat pekerjaan rumah karena pertemuan selanjutnya dilanjutkan dengan ulangan.
Berdasarkan uraian diatas dapat disimpulkan bahwa siswa memerlukan waktu untuk beradaptasi terhadap suatu pembelajaran yang mereka anggap baru, hal tersebut dapat dilihat dari peningkatan persentase ketercapaian indikator yang diamati pada setiap pertemuan.

Hasil analisis deskriptif kemampuan penalaran matematis siswa dari data posttest pada kelas eksperimen yang diajar dengan menggunakan model pembelajaran Discovery Learning yang berjumlah 21 siswa dan kelas kontrol yang diajar dengan menggunakan model pembelajaran konvensional berjumlah 22 siswa. Diperoleh data posttest kemampuan penalaran matematis siswa kelas eksperimen dan kelas kontrol disajikan pada tabel 7 berikut:

Tabel 7

Deskriptif Kemampuan Penalaran Matematis Kelas Eksperimen dan kelas Kontrol

\begin{tabular}{|l|r|r|}
\hline \multirow{2}{*}{ Mean } & \multicolumn{2}{|c|}{ Posttest } \\
\cline { 2 - 3 } & Kelas eksperimen & \multicolumn{1}{|c|}{ Kelas kontrol } \\
\hline Median & 79.1667 & 71.5909 \\
\hline Modus & 81,2500 & 75.0000 \\
\hline Standard Deviation & 87,50 & 81,25 \\
\hline Variance & 12.07615 & 13.46392 \\
\hline Skewness & 145.833 & 181.277 \\
\hline Kurtosis & -0.533 & -0.686 \\
\hline Minimum & -0.745 & -0.330 \\
\hline Maximum & 56.25 & 43.75 \\
\hline
\end{tabular}

Deskripsi kemampuan penalaran matematis siswa pada kelas eksperimen dan kelas kontrol terlihat jelas kemampuan penalaran matematis siswa kelas eksperimen lebih tinggi jika dibandingkan dengan kelas kontrol, baik dilihat dari nilai rata-rata, median, modus, nilai minimum dan nilai maksimum.

Tahap selanjutnya dalam analisis data adalah analisis inferensial. Dalam analisis inferensial, terdapat beberapa tahap analisis yang menjadi prasyarat untuk melakukan analisis uji hipotesis, yaitu analisis uji normalitas data dan analisis uji homogenitas data. Uji normalitas data dimaksudkan untuk mengetahui apakah data berasal dari populasi yang berdistribusi normal atau tidak, sedangkan uji homogenitas dimaksudkan untuk mengetahui apakah data yang diperoleh homogen terhadap populasinya atau tidak, setelah melalui syarat uji normalitas dan homogenitas maka dilanjutkan dengan uji hipotesis. Uji normalitas digunakan untuk mengetahui apakah data hasil belajar matematika kedua kelas berdistribusi normal atau tidak. Untuk menguji apakah data berdistribusi normal atau tidak digunakan statistik uji Kolmogorov-Smirnov dengan bantuan SPSS. Hasil perhitungan dapat dilihat pada Tabel 8.

Tabel 8

Hasil Analisis Uji Normalitas Data Posttest

\begin{tabular}{|c|c|c|}
\hline & Eksperimen & Kontrol \\
\hline Asymp. Sig. (2-tailed) & 0,479 & 0,529 \\
\hline
\end{tabular}

Berdasarkan hasil analisis perhitungan $0.05=\alpha$ maka $\mathrm{H}_{0}$ diterima. Hal ini berarti uji normalitas diatas, diperoleh nilai Asymp. Sig. (2-tailed) untuk kelas eksperimen $=0.479>$ bahwa data kemampuan penalaran matematis siswa pada kelas eksperimen berdistribusi 
normal. Pada kelas kontrol diperoleh nilai Asymp. Sig. $(2-$ tailed $)=0,529>0.05=\alpha$ maka $\mathrm{H}_{0}$ diterima. Hal ini berarti bahwa data hasil belajar matematika siswa pada kelas kontrol berdistribusi normal.
Uji homogenitas varians digunakan untuk mengetahui apakah varians dari kedua kelompok data tes hasil belajar matematika siswa homogen atau tidak. Berdasarkan hasil uji homogenitas varians data dari kedua kelompok sampel dengan bantuan SPSS. Hasil perhitungan dapat dilihat pada Tabel 9.

Tabel 9

Hasil Analisis Uji Homogenitas Data Posttest

\begin{tabular}{|c|c|c|c|}
\hline Levene Statistic & df1 & df2 & Sig. \\
\hline 0,230 & 1 & 41 & 0,634 \\
\hline
\end{tabular}

Dari tabel 9 di atas terlihat bahwa nilai varians yang sama. Ini berarti data post tes signifikan statistik uji Levene adalah 0,634. Nilai signifikan ini lebih besar dari taraf signifikan 0,05 ( nilai sig. $(0,634)>\alpha$ dengan $\alpha$ $=0,05)$, maka $\mathrm{H}_{0}$ diterima. Sehingga dapat disimpulkan bahwa kedua kelompok memiliki kedua kelompok yaitu yang mendapat model pembelajaran discovery learning dan model pembelajaran konvensional memiliki varians yang sama (homogen).

Tabel 11

Hasil Analisis Uji Hipotesis

\begin{tabular}{|cl|c|c|c|c|c|}
\hline \multirow{2}{*}{} & \multicolumn{2}{|c|}{$\begin{array}{c}\text { Levene's Test for } \\
\text { Equality of Variance }\end{array}$} & \multicolumn{2}{|c|}{} \\
\cline { 2 - 7 } & $\mathrm{F}$ & Sig. & $\mathrm{t}$ & $\mathrm{df}$ & Sig. (2 tailed) \\
\hline Nilai & $\begin{array}{l}\text { Equal variances } \\
\text { assumed }\end{array}$ & 0,230 & 0,634 & 1,939 & 41 & 0,059 \\
$\begin{array}{l}\text { Equal variances } \\
\text { assumed }\end{array}$ & & & 1,944 & 40,848 & 0,059 \\
\hline
\end{tabular}

Berdasarkan tabel 4.8 di atas diperoleh nilai $t_{\text {hitung }}=1,939$ atau nilai $\frac{1}{2}$ Sig. $(2-$ tailed $)=$ 0,0295 , dalam hal ini nilai $\frac{1}{2}$ Sig. $(2-$ tailed $)=$ $0,0295<\alpha$ pada $\alpha \stackrel{2}{=} 0,05$, sehingga keputusannya adalah tolak $\mathrm{H}_{0}$. Kesimpulannya, rata-rata kemampuan penalaran matematis siswa yang diajar dengan model discovery learning lebih tinggi dibandingkan dengan yang diajar dengan model pembelajaran konvensional.

\section{Pembahasan}

Jenis penelitian ini adalah penelitian eksperimen tentang Pengaruh Model discovery learning terhadap Kemampuan Penalaran Matematis Siswa Kelas VII SMP Negeri 3 Kendari. Penelitian ini mulai dilaksanakan pada tanggal 23 Februari 2018 sampai tanggal 13 Maret 2018. Waktu pembelajaran dalam pelaksanaan penelitian antara kelas eksperimen dan kelas kontrol adalah sama, masing-masing 15 jam pelajaran. Kedua kelas diberikan waktu 90 menit pada pertemuan keenam yang digunakan untuk pelaksanaan Posttest kemampuan penalaran matematis siswa.

Kedua kelas diberikan materi yang sama yaitu materi pokok garis dan sudut. Kedua kelas yaitu kelas eksperimen dan kelas kontrol diberikan bahan ajar yang sama. Perbedaan yang diberikan kepada kedua kelas ini yaitu model pembelajaran yang diberikan dimana untuk kelas eksperimen diajar dengan menggunakan model pembelajaran discovery learning sedangkan pada kelas kontrol diajar dengan menggunakan model pembelajaran konvensional.

Salah satu instrumen dalam penelitian ini yang dianalisis berupa lembar observasi untuk guru dan siswa pada kelas eksperimen. Lembar observasi ini dimaksudkan untuk mengontrol pelaksanaan pembelajaran dengan model pembelajaran discovery learning setiap kali pertemuan.

Berdasarkan hasil observasi pelaksanaan pembelajaran dengan model pembelajaran discovery learning diperoleh persentase keberhasilan pelaksanaan pembelajaran oleh 
guru pada pertemuan pertama sebesar $70,59 \%$. Hal ini karena guru masih dalam tahap penyesuaian diri di kelas. Selain itu, ada kegiatan yang tidak dilaksanakan sesuai itemitem yang dicantumkan dalam lembar observasi guru dengan model pembelajaran discovery learning yakni guru tidak memotivasi siswa, tidak menyampaikan tujuan pembelajaran, serta guru tidak menyampaikan garis-garis besar kegiatan model pembelajaran discovery learning. Pada kegiatan inti, guru lupa meminta siswa untuk mengolah atau menghitung untuk memperoleh jawaban apakah sesuai hipotesis atau tidak, guru langsung menyuruh siswa untuk mengerjakan LKS yang telah dibagikan kepada siswa. Pada kegiatan penutup, karena kehabisan waktu, guru tidak menyampaikan materi yang akan dipelajari pada pertemuan selanjutnya. Tingkat keberhasilan pelaksanaan pembelajaran dengan model pembelajaran discovery learning pada pertemuan kedua sampai keempat mengalami peningkatan sampai mencapai $95,65 \%$. Hal ini karena guru sudah dapat menyesuaikan diri dengan model pembelajaran discovery learning.

Selama 5 kali tatap muka pada proses pembelajaran dengan model pembelajaran discovery learning pada kelas eksperimen pada materi garis dan sudut menunjukkan pelaksanaan yang sangat baik hal ini didukung dengan keatifan siswa yang terus meningkat pada setiap kali pertemuan. Pada pertemuan pertama keaktifan siswa mencapai $70,59 \%$ yang mana terus meningkat hingga mencapai persentasi $88,24 \%$. Pada pertemuan pertama beberapa siswa kurang mendengarkan tujuan pembelajaran yang disampaikan guru, beberapa siswa tidak melakukan kerjasama dengan kelompok lain bila mengalami kesulitan dalam menemukan penyelesaian masalah, beberapa siswa juga tidak melakukan kerjasama yang aktif dan terarah, serta pada kegiatan akhir, karena guru lupa menyampaikan materi yang akan dipelajari pada pertemuan selanjutnya, sehingga siswa juga tidak mendengarkan materi apa yang akan dipelajari selanjutnya. Akan tetapi, pada pertemuan-pertemuan selanjutnya keaktifan siswa mulai mengalami peningkatan, dimana siswa sudah mampu melakukan kerjasama yang aktif dan terarah, siswa juga sudah tidak malu dengan guru untuk menanyakan materi atau penyelesaian yang tidak dipahami, serta sudah mendengarkan materi apa yang akan dipelajari pada pertemuan selanjutnya.

Deskripsi hasil tes kemampuan penalaran matematis siswa pada kelas eksperimen dan kelas kontrol, mula-mula dimulai dari tahap persiapan instrument tes. Soal-soal Posttest yang digunakan terlebih dahulu diujicobakan dengan tujuan untuk mengetahui validitas dan reliabilitasnya. Tes tersebut diujicobakan kepada 29 siswa di kelas $\mathrm{VIII}_{1}$ SMP Negeri 8 Kendari pada tanggal 7 Maret 2018. Selanjutnya diadakan pengolahan data untuk mengetahui soal yang memenuhi kriteria valid dan reliabel. Dari hasil perhitungan menunjukkan bahwa dari kedelapan soal hanya 4 butir soal yang valid. Sehingga 4 soal yang digunakan sebagai instrumen tes kemampuan penalaran matematika. Reliabilitas tes berada pada kategori sedang dengan $\mathrm{r}_{11}$ adalah 0,566.

Berdasarkan hasil analisis deskriptif dari data yang diperoleh melalui tes kemampuan penalaran matematis siswa yang diujikan pada kelas eksperimen diperoleh rata-rata 79,16 lebih tinggi dari nilai rata-rata yang diperoleh siswa pada kelas kontrol yaitu 71,59. Dari segi keragaman data (varians), kelas eksperimen memiliki varians data 145,83 sedangkan kelas kontrol memiliki varians 181,27 . Nilai varians tersebut menunjukkan data hasil posttest kelas kontrol lebih beragam dari kelas eksperimen. Standar deviasi (simpangan baku) kelas eksperimen sebesar 12,07, sedangkan standar deviasi untuk kelas kontrol sebesar 13,46. Hal ini menunjukkan bahwa kemampuan penalaran matematis siswa pada kelas kontrol lebih beragam dalam arti bahwa kemampuan penalaran matematis siswa menyebar jauh dari rata-rata. Median (nilai tengah) dari kelas eksperimen adalah 81,25 , sedangkan median kelas kontrol adalah 75,00. Nilai yang sering muncul (modus) pada kelas eksperimen adalah sebesar 87,5, sedangkan pada kelas kontrol yaitu sebesar 81,25. Hal ini menunjukkan bahwa ada pengaruh penggunaan model pembelajaran discovery learning terhadap kemampuan penalaran matematis pada materi garis dan sudut.

Sebelum dilakukannya analisis hipotesis, terlebih dahulu dilakukan uji prasyarat berupa uji normalitas dan uji homogenitas menggunakan bantuan aplikasi SPSS 21. Pada uji normalitas peneliti menggunakan uji Kolmogorov-Smirnov. Uji normalitas dapat 
dilihat dari nilai sig. Jika nilai sig > dari 0,05 maka data dapat dikatakan normal. Dari hasil analisis data uji normalitas diperoleh Asymp. Sig (2-tailed) pada kelas eksperimen adalah 0,479 dan Asymp. Sig (2-tailed) pada kelas kontrol adalah 0,529. Karena kedua kelas memiliki nilai sig > 0,05 maka dapat disimpulkan bahwa data pada kedua kelas berdistribusi normal.

Uji prasyarat kedua adalah uji homogenitas. Uji homogenitas digunakan untuk mengetahui apakah kelas yang dijadikan sampel penelitian homogen atau tidak. Dalam pengujian homogenitas dapat dilihat dari nilai sig. Jika nilai sig > 0,05 maka data dapat dikatakan homogen. Dari hasil uji homogenitas diperoleh nilai sig. kelas eksperimen dan kelas kontrol sebesar 0,634. Karena 0,634> 0,05 maka dapat disimpulkan bahwa kelas yang dijadikan sampel penelitian adalah kelas yang homogen.

Setelah melakukan uji prasyarat peneliti melakukan uji hipotesis menggunakan statistik uji-t yang digunakan untuk mengetahui rata-rata kemampuan penalaran matematis siswa yang diajar dengan model pembelajaran Discovery learning lebih tinggi daripada siswa yang diajar dengan model pembelajaran konvensional. Berdasarkan analisis data uji-t (Independent sample t-test) menggunakan bantuan aplikasi SPSS 21 diperoleh nilai $\frac{1}{2}$ sig (2-tailed) sebesar $0,029<\alpha=0,05$ sehingga $\mathrm{H}_{0}$ ditolak.

Deskripsi hasil tes kemampuan penalaran matematis siswa pada kelas eksperimen dan kelas kontrol, mula-mula dimulai dari tahap persiapan instrument tes. Soal-soal Posttest yang digunakan terlebih dahulu diujicobakan dengan tujuan untuk mengetahui validitas dan reliabilitasnya. Tes tersebut diujicobakan kepada 29 siswa di kelas VIII $_{1}$ SMP Negeri 8 Kendari pada tanggal 7 Maret 2018. Selanjutnya diadakan pengolahan data untuk mengetahui soal yang memenuhi kriteria valid dan reliabel. Dari hasil perhitungan menunjukkan bahwa dari kedelapan soal hanya 4 butir soal yang valid. Sehingga 4 soal yang digunakan sebagai instrumen tes kemampuan penalaran matematika. Reliabilitas tes berada pada kategori sedang dengan $r_{11}$ adalah 0,566.

Berdasarkan hasil analisis deskriptif dari data yang diperoleh melalui tes kemampuan penalaran matematis siswa yang diujikan pada kelas eksperimen diperoleh rata-rata 79,16 lebih tinggi dari nilai rata-rata yang diperoleh siswa pada kelas kontrol yaitu 71,59. Dari segi keragaman data (varians), kelas eksperimen memiliki varians data 145,83 sedangkan kelas kontrol memiliki varians 181,27 . Nilai varians tersebut menunjukkan data hasil posttest kelas kontrol lebih beragam dari kelas eksperimen. Standar deviasi (simpangan baku) kelas eksperimen sebesar 12,07, sedangkan standar deviasi untuk kelas kontrol sebesar 13,46. Hal ini menunjukkan bahwa kemampuan penalaran matematis siswa pada kelas kontrol lebih beragam dalam arti bahwa kemampuan penalaran matematis siswa menyebar jauh dari rata-rata. Median (nilai tengah) dari kelas eksperimen adalah 81,25, sedangkan median kelas kontrol adalah 75,00. Nilai yang sering muncul (modus) pada kelas eksperimen adalah sebesar 87,5, sedangkan pada kelas kontrol yaitu sebesar 81,25. Hal ini menunjukkan bahwa ada pengaruh penggunaan model pembelajaran discovery learning terhadap kemampuan penalaran matematis pada materi garis dan sudut.

Sebelum dilakukannya analisis hipotesis, terlebih dahulu dilakukan uji prasyarat berupa uji normalitas dan uji homogenitas menggunakan bantuan aplikasi SPSS 21. Pada uji normalitas peneliti menggunakan uji Kolmogorov-Smirnov. Uji normalitas dapat dilihat dari nilai sig. Jika nilai sig > dari 0,05 maka data dapat dikatakan normal. Dari hasil analisis data uji normalitas diperoleh Asymp. Sig (2-tailed) pada kelas eksperimen adalah 0,479 dan Asymp. Sig (2-tailed) pada kelas kontrol adalah 0,529. Karena kedua kelas memiliki nilai sig > 0,05 maka dapat disimpulkan bahwa data pada kedua kelas berdistribusi normal.

Uji prasyarat kedua adalah uji homogenitas. Uji homogenitas digunakan untuk mengetahui apakah kelas yang dijadikan sampel penelitian homogen atau tidak. Dalam pengujian homogenitas dapat dilihat dari nilai sig. Jika nilai sig > 0,05 maka data dapat dikatakan homogen. Dari hasil uji homogenitas diperoleh nilai sig. kelas eksperimen dan kelas kontrol sebesar 0,634. Karena 0,634>0,05 maka dapat disimpulkan bahwa kelas yang dijadikan sampel penelitian adalah kelas yang homogen.

Setelah melakukan uji prasyarat peneliti melakukan uji hipotesis menggunakan statistik uji-t yang digunakan untuk mengetahui rata-rata 
kemampuan penalaran matematis siswa yang diajar dengan model pembelajaran Discovery learning lebih tinggi daripada siswa yang diajar dengan model pembelajaran konvensional. Berdasarkan analisis data uji-t (Independent sample t-test) menggunakan bantuan aplikasi SPSS 21 diperoleh nilai $\frac{1}{2}$ sig (2-tailed) sebesar $0,029<\alpha=0,05$ sehingga $\mathrm{H}_{0}$ ditolak.

Dengan demikian dapat disimpulkan bahwa rata-rata kemampuan penalaran matematis siswa yang diajar dengan model pembelajaran discovery learning lebih tinggi daripada siswa yang diajar dengan model pembelajaran konvensional. Jadi, berdasarkan uraian diatas maka model pembelajaran discovery learning berpengaruh daripada model pembelajaran konvensional hal ini sesuai dengan Bani (2014) dalam penelitiannya menyimpulkan bahwa terjadi peningkatan yang lebih tinggi pada siswa kelas discovery learning (kelas eksperimen) dibandingkan dengan kelas konvensional (kelas kontrol) serta penelitian yang dilakukan oleh Fitriyah (2017) menyimpulkan hasil belajar matematika siswa yang menggunakan model discovery learning lebih baik dari hasil belajar matematika yang menggunakan model pembelajaran konvensional. Model discovery learning ini mendorong siswa untuk mengembangkan cara belajar aktif dengan menemukan dan menyelidiki sendiri dalam pembelajaran dan mampu memecahkan masalah serta dapat menarik sebuah kesimpulan/solusi yang tepat dari suatu masalah. Dengan demikian, siswa lebih terlatih lagi dalam memecahkan suatu masalah ataupun menarik kesimpulan/solusi yang tepat.

\section{Simpulan dan Saran}

\section{Simpulan}

1. Aktivitas belajar dengan menggunakan model discovery learning pada kelas VII SMP Negeri 3 Kendari terkategori baik. Secara keseluruhan persentase tingkat keterlaksanaan pembelajaran oleh guru pada 5 kali pertemuan berturut-turut adalah $73,91 \%, \quad 78,26 \%, 82,61 \%, 86,96$ dan $95,65 \%$, Sedangkan persentase tingkat keaktifan siswa pada 5 kali pertemuan berturut-turut adalah 70,59\%, 76,47\%, $76,47 \%, 82,35$ dan $88,24 \%$, persentase ini terkategori sangat baik dengan rata-rata persentase keaktifan siswa yang mengikuti pembelajaran dengan model discovery learning adalah $78,82 \%$.

2. Gambaran kemampuan penalaran matematis siswa kelas $\mathrm{VII}_{\mathrm{H}}$ SMP Negeri 3 Kendari yang diajar dengan menggunakan model discovery learning pada pokok bahasan garis dan sudut diperoleh nilai rata-rata 79,16 ; median 81,25 ; modus 87,50 ; standar deviasi 12,07 ; varians 145,83 ; nilai minimum 56,25 dan nilai maksimum 93,75, kualifikasi kemampuan penalaran matematis siswa pada kualifikasi sangat tinggi tidak ada, kualifikasi tinggi terdapat 12 siswa dan kualifikasi cukup terdapat 7 siswa, klasifikasi kemampuan penalaran matematis siswa pada kategori sangat tinggi sebanyak 4 siswa, kategori tinggi sebanyak 5 siswa, kategori cukup sebanyak 6 siswa, kategori rendah terdapat 3 siswa serta kategori sangat rendah sebanyak 3 siswa dan untuk kategori indikator kemampuan penalaran rata-rata siswa sangat baik dalam hal menyajikan pernyataan matematika seecara lisan, tertulis, gambar dan diagram.

3. Gambaran kemampuan penalaran matematis siswa kelas VII SMP Negeri 3 Kendari yang diajar dengan menggunakan model konvensional pada pokok bahasan garis dan sudut diperoleh nilai rata-rata 71,59; median 75,00; modus 81,25; standar deviasi 13,46; varians 181,27 ; nilai minimum 43,75 dan nilai maksimum 87,50, klasifikasi kemampuan penalaran matematis siswa pada kategori sangat tinggi tidak ada, kategori tinggi sebanyak 4 siswa dan kategori cukup sebanyak 8 siswa, kategori rendah sebanyak 4 siswa dan untuk kategori indikator kemampuan penalaran rata-rata siswa sangat baik dalam melakukan manipulasi matematika.

4. Terdapat pengaruh yang signifikan penggunaan model discovery learning terhadap kemampuan penalaran matematis siswa di kelas VII SMP Negeri 3 Kendari.

\section{Saran}

Berdasarkan hasil penelitian ini, maka peneliti mengemukakan saran-saran sebagai berikut:

1. Indikator kemampuan memeriksa suatu argument dan menarik kesimpulan dari 
suatu pernyataan dikelas konvensional masih kurang, diharapkan guru dapat menggunakan model pembelajaran discovery learning untuk meningkatkan kemampuan penalaran matematis.

2. Bagi peneliti yang hendak mengembangkan penelitian ini dapat melakukannya pada pokok bahasan lain dengan memperhatikan alokasi waktu pembelajaran sehingga proses pembelajaran dengan model discovery learning bisa berjalan lebih optimal.

\section{Daftar Pustaka}

Ahiri, J dan A. Hafid. (2011). Evaluasi Pembelajaran dalam Konteks KTSP. Humaniora : Bandung.

Ansyar, Mohamad. (2015). Kurikulum (Hakikat, Fondasi, Desain dan Pengembangan). Kencana Prenadamedia Group : Jakarta.

Arikunto, Suharsimi. (2005). Dasar-dasar Evaluasi Pendidikan. Bumi Aksara : Jakarta.

Bani, Asmar. (2011). 'Meningkatkan Kemampuan Pemahaman dan Penalaran Matematik Siswa Sekolah Menengah Pertama Melalui Pembelajaran Penemuan Terbimbing'. Jurnal Edisi Khusus.1(1): 15.

Fitriyah, dkk. (2017). 'Pengaruh Model Pembelajaran Discovery Learning terhadap Hasil Belajar Matematika Siswa MAN Model Kota Jambi'. Jurnal 9(2): 108
Fitmawati, Entya Esa. (2016). Efektivitas Model Pembelajaran Discovery Learning Terhadap Hasil Belajar Siswa pada Materi Perbandingan Ditinjau dari Kemampuan Matematika. Skripsi. Universitas Nusantara PGRI Kediri. Kediri.

Jamilun. (2016). Pengaruh Penerapan Model Pembelajaran Berbasis Masalah terhadap Kemampuan Penalaran Matematis Siswa Kelas VIII SMP Negeri 1 Kontukowuna. Skripsi. Universitas Halu Oleo. Kendari.

Jihad, Asep dan Haris, Abdul. (2012). Evaluasi Pembelajaran. Multi Pressindo: Yogyakarta.

Mulyatiningsih, Endang. (2011). Metode Penelitian Terapan Bidang Pendidikan. Alfabeta: Bandung.

Priansa, Donni Juni. (2015). Manajemen Peserta Didik dan Model Pembelajaran. Alfabeta: Bandung.

Suprihatiningrum, Jamil. (2016). Strategi Pembelajaran Teori \& Aplikasi. ArRuzz Media: Yogyakarta. 